\title{
Slagmarkens moral og risikofri krig med droner ${ }^{1}$
}

Anders Henriksen, lektor i folkeret, Københavns Universitet

Jens Ringsmose, chef for Institut for Militære Operationer, Forsvarsakademiet

"No bastard ever won a war by dying for his country. He won it by making the other poor dumb bastard die for his country."

- George S. Patton

"Danger is the raison d'être of war, opposition its indispensable prerequisite; conversely, unopposed killing does not count as fighting but as murder or, in case it takes place under legal auspices, as execution.”

- Martin van Creveld

Det er ikke vanskeligt at forstå, at en lang række stater i disse år enten udvikler eller køber bevæbnede droner. I modsætning til bemandede kampfly, så styres droner af en pilot på jorden, og det betyder i praksis, at det ubemandede fartøj kan anvendes til usikre områder uden den vanlige risiko for, at pilotens helbred lider overlast. Det er da også først og fremmest udsigten til at kunne anvende væbnet magt mod fjenden og dennes kombattanter uden risiko for tab på egen side, der gør, at dronerne er blevet så attraktive og efterspurgte. Det gælder ikke mindst i Vesten, hvor krigene i Afghanistan og Irak har ført til en udbredt 'interventionstræthed'. Det er dog ikke kun vestlige stater, der har fået øjnene op for de bevæbnede droners fordele - det samme har lande som eksempelvis Kina, Iran, Rusland og Nigeria, der alle er i færd med at erhverve sig de nye fjernstyrede våbensystemer (Kaag \& Kreps 2014, kap. 2).

Det amerikanske droneprogram i lande som Pakistan, Yemen, Somalia og senest Libyen illustrerer imidlertid også med al mulig tydelighed, at dronekrig er alt andet end ukontroversiel. En lang række kommentatorer og institutioner - herunder FN's 'special rapporteurs' - har kritiseret amerikanerne for deres udstrakte brug af bevæbnede droner i 'krigen mod terror' (se fx Emmerson 2014). Mens nogle har rettet deres kritik mod Washingtons til tider tvivlsomme juridiske begrundelser for dronekrigen, der ikke er

\footnotetext{
${ }^{1}$ Forfatterne takker for den anonyme reviewers grundige og meget konstruktive kommentarer.
} 
begrænset til 'slagmarken' i traditionel forstand, har andre påpeget den negative strategiske slagside, der kan være forbundet med at gennemføre droneangreb, som tilsyneladende koster et stort antal civile livet. Denne juridisk og strategisk funderede kritik af dronerne er i praksis rettet mod den måde, hvorpå dronerne anvendes.

Det interessante er imidlertid, at den udbredte kritik af - og modstand mod dronekrig tilsyneladende ikke kun synes at kunne reduceres til et spørgsmål om, hvor og mod hvem de bevæbnede droner anvendes, og hvor megen utilsigtet skade droneangreb forårsager. Og det er her, at nærværende essay tager sit afsæt. Vi søger nemlig at forstå det mere grundlæggende ubehag, der omgærder den form for krigsførelse, som de bevæbnede droner repræsenterer (se fx Strawser 2013a).

Det er vores påstand, at den sidstnævnte form for kritik af dronekrig forst og fremmest udspringer af et sjældent artikuleret - og måske endog ubevidst moralpsykologisk ubehag ved det, der betegnes som 'risikofri krig'. Vores ærinde er at pege på det paradoksale forhold, at det er de samme ting, som gør dronerne attraktive for både civile og militære beslutningstagere - muligheden for at kunne anvende væbnet magt mod fjenden uden risiko for tab på egen side - der samtidig ligger til grund for en del af den uvilje, der omgærder dronerne.

De bevæbnede droner er efter vores opfattelse i høj grad blevet et symbol på en moderne form for krigsførelse, hvor den ene part i konflikten (som regel Vesten) er så militært overlegen, at den er i stand til at eliminere fjendens styrker uden at risikere egne soldaters liv og lemmer. Og det er netop denne form for krigsførelse, der af mange opleves som moralsk problematisk. Anvendelsen af de ubemandede, bevæbnede fartøjer strider nemlig mod en udbredt antagelse om, at krig ikke bør være en fuldstændig ensidig affære, hvor det kun er den ene side, der slår ihjel, og den anden side, der dør. Den moralsk-funderede antagelse synes med andre ord at være, at der bør være en form for gensidighed i de stridende parters magtanvendelse, og at begge parter skal være eksponeret for slagmarkens farer. Der eksisterer således en oplevet grænse for, hvor asymmetrisk krigen må være. Og de bevæbnede droner krydser i kritikkernes øjne denne grænse.

Det primære formål med essayet er altså at beskrive, hvordan i hvert fald dele af den udbredte kritik af dronekrig er forbundet med et mere grundlæggende moralpsykologisk ubehag, der er knyttet til forestillingen om risikofri krig. Vi forholder os hverken til de politiske, strategiske eller juridiske argumenter for eller imod brugen af bevæbnede droner, og vi afstår også fra at fælde moralsk dom over dronerne. Vores sigte er mere begrænset: Vi søger at blotlægge og forstå en moralsk-funderet modvilje mod den form for risikofri krig, som vi mener, at dronerne er udtryk for.

Essayet rummer to hovedafsnit: Vi lægger ud med at spore den moralsk funderede modvilje mod bevæbnede droner til en forestilling om, at krig er mere end blot en strategisk og juridisk aktivitet. Med afsæt i Martin van Crevelds (1991) fortolkning af krigens væsen gør vi gældende, at krig i høj grad også skal betragtes og forstås som en moralsk praksis, der er styret af ikke-formaliserede normer og værdier. Med henblik på at spore de i denne sammenhæng væsentligste moralske forestillinger om den 'rigtige' 
krig introducerer vi i artiklens anden del Paul W. Kahns (2002) tanker om den moralske betydning af krigens gensidighed. Vi søger dermed at identificere nogle af de basale moralske forestillinger, som anvendelsen af bevæbnede droner kolliderer med. Vores argument er alt i alt ret simpelt: Vores holdning til krig styres ikke kun af strategiske og juridiske overvejelser, men i høj grad også af moralpsykologiske dispositioner forankret i ikke-formaliserede normer. Forestillingen om at krig bør være præget af en form for 'risiko-gensidighed', er en væsentlig norm i denne sammenhæng. Det ubehag, som mange føler ved brugen af de bevæbnede droner, udspringer med andre ord af forestillingen om den risikofrie krig.

\section{Krigens moralske dimension}

For at forstå den mere eller mindre artikulerede aversion mod brugen af bevæbnede droner, som mange forskere, beslutningstagere og helt almindelige mennesker nærer, er det nødvendigt at anskue krig og krigsførelse som mere end instrumentelle aktiviteter, der ene og alene er underlagt et juridisk normsystem. Væbnet konflikt handler om meget mere end strategiske overvejelser og overholdelse af internationale konventioner og sædvaner for lovlig krigsførelse. Det er ganske vist korrekt, at flere har udtrykt kritik af anvendelsen af bevæbnede droner, fordi de mener, at dronerne er kontraproduktive i en strategisk/instrumentel forstand (se fx Kaag \& Kreps 2014, kap. 3; Kilcullen \& Exum 2009) og/eller fordi den konkrete anvendelse af dronerne efter kritikernes opfattelse strider mod folkeretten. Men den form for ubehag, der omgærder dronerne, udspringer af en grundantagelse om, at selv krige, der giver strategisk mening, og som holder sig inden for de retlige normer, skal være moralsk forsvarlige.

Der findes en omfattende litteratur om krigens moralske og etiske fundament, men et af de primære værker, der bidrager til vores undersøgelse af de uformelle normer, og som har indflydelse på vores opfattelser af og holdninger til risikofri krig, er Martin van Crevelds banebrydende bog fra 1991, The Transformation of War. Crevelds primære ærinde er netop at udfordre den konventionelle forståelse af krig som en instrumentel aktivitet, der udøves for at nå et politisk mål. Crevelds ambition er med andre ord at supplere Carl von Clausewitz' klassiske beskrivelse af krig som den rationelle forfølgelse af politiske mål med væbnede midler (Clausewitz 1976). I modsætning til Clausewitz tager Creveld udgangspunkt i krigen, som den tager sig ud og opleves ude på slagmarken. Og her opleves krigen ikke først og fremmest som de politiske beslutningstageres rationelle instrument, der skal forfølge et givent politisk mål, men i stedet som en social aktivitet, der er styret af grupper og individers normer, værdier og basale menneskelige behov. Hos Creveld ser vi med andre ord ikke krigen som et resultat af modsatrettede politiske interesser, men derimod med afsæt i de individer, der udkæmper den.

Det er ifølge Creveld i virkeligheden ret simpelt: Grunden til at mænd går i krig er, at de stræber efter at blive krigere. Årsagen er er kun undtagelsesvist, at de er villige 
til at kæmpe for politiske mål eller for statens interesser. Soldaten er i stort omfang drevet af et ønske om at være kriger og om at besidde de dyder, der karakteriserer den 'gode kriger' - først og fremmest mod, ridderlighed, ære, loyalitet og mandighed. Eller som Creveld selv formulerer det: "Probably in most wars ever waged the vast majority of combatants were not even aware of the exact nature of the political considerations for which they were supposed to be fighting" (Creveld 1991, 187). Vi mener, at Crevelds klare fokus på krigen som en meningsskabende og normbaseret aktivitet snarere end et rationelt politisk instrument skaber et godt udgangspunkt for at forstå en normbaseret modvilje mod dronekrig. Mens det således er Clausewitz' ambition at bidrage til en forståelse af krigen som et politisk instrument, der kan og bør anvendes strategisk, så er Creveld optaget af alle de ikke-rationelle forhold, som informerer og sætter rammer for krigen.

En af de mest grundlæggende - men sjældent udtrykte - etiske principper for hvordan krig bør føres, er ideen om gensidighed ('reciprocitet'). Princippet fordrer, at det i høj grad er den gensidige fare og risiko forbundet med deltagelse i krigen, der gør drab og lemlæstelse på slagmarken moralsk forsvarlig (Creveld 1991, kap. 6; se også Kaag \& Kreps 2014, kap. 5; Sparrow 2013). Hvis fjenden er helt og aldeles forsvarsløs, er det ganske enkelt moralsk forkasteligt at slå ham ihjel. Som Michael Walzer formulerer det: "You can't kill unless you are prepared to die" (2004, 101). Set i det lys er krigsførelsen altid baseret på en etisk præmis om, at "opponents should be of broadly comparable nature" (Creveld 1991, 173). Eller:

\footnotetext{
"The other point where conventional strategic thought goes astray concerns the premise that war consists of members of one group killing those of another. In fact, war does not begin when some people start killing others; instead, it starts at the point where they themselves risk being killed in return. Those, and there are always some, who engage in the former but not in the latter are not called warriors but butchers, murderers, assassins, or any number of even less complimentary epithets... killing people who do not or cannot resist does not count as war. Nor are those responsible for such killing likely to earn the respect deserved for warriors." (Creveld 1991, 159)
}

Princippet om gensidighed er baseret på en antagelse om, at overdreven 'risikoasymmetri' gør krigen til en moralsk uforsvarlig aktivitet. Eller omvendt: Moralsk forsvarlig krig er i hvert fald karakteriseret ved et minimum af gensidighed.

Vestens (succesfulde) bestræbelser på at gøre det militære instrument så effektivt og dødbringende som muligt udfordrer gensidighedsprincippet og herved også de væbnede styrker og de politiske beslutningstagere. I overensstemmelse med Clausewitz' tanker og det, som Max Weber benævnte 'Zweckrationalismus,' har Vesten nemlig tilstræbt at instrumentalisere krigen og opnå den størst mulige risiko-asymmetri til egne styrkers fordel. I en vestlig optik har krig i en vis forstand altid handlet om at gøre krigen så farlig som mulig for fjenden - 'the other poor dumb bastard' - og så sikker som mulig for egne soldater. Moderne krig er derfor blevet en meget ulig affære, som i 
stadig ringere omfang lever op til princippet om gensidighed. Derfor bliver vi i stigende omfang mindet om, at krig handler om meget mere end blot instrumentelle hensyn og rationalitet. Jo tættere vi kommer på at kunne elimere risikoen ved krig, jo større bliver vores moralpsykologiske ubehag.

Den tiltagende brug af bevæbnede droner illustrerer efter vores opfattelse, at der er en grænse for, hvor langt vi kan gå i bestræbelserne på at kunne anvende væbnet magt mod fjenden uden risiko for egne tab uden at komme i konflikt med en 'logic of appropriateness' og en etisk baseret antagelse om, at krig (hvis den skal være moralsk forsvarlig) bør være en gensidig aktivitet. I et weberiansk perspektiv er det, vi har været vidner til i de seneste par århundreder, 'krigens af-fortryllelse'. Og det er begyndt at gøre os ubehageligt til mode. Pointen er, at det ubehag, vi føler, viser, at moralske normer og etisk betingede forestillinger om et særligt 'krigeretos' stadig præger vores forståelse af krig, og den måde krigen bør føres på. Trods årelange bestræbelser på at instrumentalisere, rationalisere og disciplinere krigsførelsen, har vi endnu ikke været i stand til at give slip på dens moralske dimension.

\section{Den risikofri krigs paradoks}

Paul W. Kahn fra Yale University gør i en ofte citeret artikel fra 2002 gældende, at der er et paradoks forbundet med risikofri krig (Kahn 2002). Kahn anerkender til fulde, at politiske og militære beslutningstagere er underlagt en etisk forpligtelse om at søge at minimere risikoen for tab blandt egne soldater. Ifølge Paul W. Kahn er det ikke desto mindre et paradoks, at stater til stadighed gør deres yderste for at beskytte deres egne soldater mod risiko i krig, men at det efter hans opfattelse netop er den gensidige accept af fysisk risiko, som udgør det moralske fundament for voldsanvendelsen soldaterne imellem. Som Kahn udtrykker det: "The paradox of riskless warfare arises when the pursuit of asymmetry undermines reciprocity. Without reciprocal imposition of risk, what is the moral basis for injuring the morally innocent?" (Kahn 2002, 2).

Når vi accepterer, at soldater slår hinanden ihjel, skyldes det ifølge Kahn hverken, at vi mener, at soldater gør noget moralsk forkert, når de begiver sig ud på slagmarken, eller at den politiske sag, som soldaterne er sat til at kæmpe for, nødvendigvis er mere eller mindre amoralsk end andre politiske sager. Soldater anses derimod traditionelt for at være moralsk ligeværdige individer, der ikke har gjort sig skyldige i nogen 'forkert' adfærd, så længe de overholder krigens regler. Når vi accepterer, at soldater slår hinanden ihjel, er det ifølge Kahn, fordi soldaterne har ret til at bruge dødelig magt mod hinanden, og at det derfor i praksis for den enkelte soldat handler om at slå ihjel eller at blive slået ihjel. Slagmarkens moralske fundament er herved nært beslægtet med det moralske grundlag, der understøtter individuelt selvforsvar (Kahn 2002, 3). På samme måde som et individ er berettiget til at forsvare sig selv mod en aggressor, er en soldat berettiget til at slå den fjende ihjel, der prøver at dræbe ham. 
Kahns analyse indikerer, at den totale asymmetri og fraværet af gensidig risiko skaber problemer for såvel den stærke såvel som den svage part i den risikofrie krig. For mens den stærke part, der ikke løber nogen risiko, er ude af stand til at retfærdiggøre sin magtanvendelse ved at henvise til nødvendigheden af at forsvare soldaterne mod en overhængende risiko - der er jo ingen - så er den svage part i praksis ude af stand til at forsvare sig mod den stærke parts brug af væbnet magt. I det omfang, at det er nødvendigheden af selvforsvar, som udgør det moralske fundament for brug af dødelig magt i krig, så gør den totale asymmetri det i praksis umuligt for parterne at kæmpe på en moralsk forsvarlig måde. Kahns argument er indlysende relevant i forhold til fremkomsten af bevæbnede droner. For hvis det etiske grundlag for at dræbe fjendens kombattanter er knyttet til eksistensen af gensidig risiko, så rejser den risikofrie dronekrigsførelse oplagte etiske spørgsmål. Som Kahn selv bemærker:

\begin{abstract}
"A regime capable of targeting and destroying others with the push of a button, with no human intervention but only the operation of the ultimate high tech weapon, propels us well beyond the ethics of warfare. Such a deployment of force might be morally justified — it might be used to promote morally appropriate ends - but we cannot appeal to the morality of warfare to justify this mode of combat." $(2002,3)$
\end{abstract}

Ifølge Kahn betyder fraværet af gensidig risiko, at det, der foregår, slet ikke kan betegnes som krigsførelse, men derimod må anskues som en form for 'politivirksomhed'. Og skiftet fra krigsførelse til politivirksomhed er vigtigt, fordi politivirksomhed er baseret på et andet moralsk grundlag end krigsførelse. I modsætning til krigsførelse, så er politivirksomhed nemlig baseret på en grundantagelse om, at det kun er de personer, der har foretaget sig noget moralsk forkasteligt - the 'morally guilty' - der må finde sig i, at de risikerer at lide overlast. Politivirksomhed er med andre ord kendetegnet ved, at individer gøres til genstand for magtanvendelse på grund af det, de har gjort, og ikke hvem de er (Kahn 2002, 4).

For Kahn består det problematiske ikke i overgangen fra krig til politivirksomhed, og Kahn påstår ikke, at staterne bør tilstræbe en 'fair fight', hvor det accepteres, at også ens egne soldater skal løbe en risiko for at blive slået ihjel. Kahn anerkender som nævnt eksistensen af en moralsk forpligtelse til at søge at minimere den risiko, som egne styrker udsættes for. Det problematiske opstår derimod ifølge Kahn, hvis det ændrede moralske grundlag for voldsudøvelsen ikke kommer til udtryk i den faktiske anvendelse af magt. Problemet er med andre ord sammenblandingen af "the traditional morality of the battlefield with the appropriate morality for contemporary, international policing." Pointen er altså, at hvis det, dronerne foretager sig, er politivirksomhed og ikke krigsførelse, så bør det retlige normsystem, der regulerer anvendelsen af droner, gentænkes (Kahn 2002, 4). I praksis vil det bl.a. betyde, at magtanvendelsen kun rettes mod de personer, som har begået en moralsk forkastelig handling (Kahn 2002, 7). Sat på spidsen vil det endvidere også betyde, at der introduceres en egentlig procedure med 
egnede retssikkerhedsgarantier, når det vurderes, hvem magtanvendelsen må rettes imod. Den blotte konstatering af, at en person bærer fjendens uniform, er utilstrækkelig til at gøre denne til genstand for dødeligt magt.

\section{Afrunding}

Ærindet med dette essay har først og fremmest været at bidrage til forståelsen af det ubehag, som mange nærer, når det gælder anvendelsen af bevæbnede droner. Med afsæt i blandt andre Paul W. Kahn og Martin van Crevelds forskning har vi sporet den moralpsykologiske modvilje imod dronerne til i stort omfang at hænge sammen med den 'risikofrihed', som dronerne repræsenterer. Når reciprociteten forsvinder, og krigen bliver en ensidig affære, hvor den ene part anvender væbnet magt, og den anden part dør, så opstår der tvivl om, hvorvidt krigsførelsen er legitim.

Det hører med til historien, at de bevæbnede droner ikke er det eneste risikofrie våbensystem, som især vestlige stater råder over. Der er således heller ikke megen personlig risiko forbundet ved at affyre krydsermissiler fra ubåde eller ved at gennemføre luftbombardementer fra stor højde i stater uden fungerende luftforsvarssystemer. Der var eksempelvis ikke meget symmetri i den militære luftkampagne mod Serbien og Beograd i 1999 og for den sags skyld i luftoperationerne i Libyen i foråret 2011 eller i de igangværende operationer mod Islamisk Stat i Irak og Syrien. Kahns kritik af den påståede sammenblanding mellem slagmarkens moral og nutidig international politivirksomhed kan derfor heller ikke kun anses som en eventuel kritik af anvendelsen af bevæbnede droner som et våbensystem, men derimod af ekstremt asymmetrisk krig - og dermed af en stor del af Vestens krige - som sådan.

Når vi tilsyneladende ikke føler den samme grad af ubehag ved risikofri krig, når den udfolder sig som en luftoperation eller gennem anvendelsen af krydsermissiler, skyldes det i vores optik, at de satellit-styrede droner transcenderer stort set alle geografiske begrænsninger. I modsætning til kampfly og - i mindre udstrækning krydsermissiler, så er der reelt ingen geografisk forbindelse mellem operatøren af våbnet og slagmarken. Dronepiloten kan sidde varmt, tørt og sikkert på den anden side af kloden, mens jagerpiloten og operatøren af krydsermissilet trods alt må opholde sig i nærheden af slagmarken. De ubemandede systemer repræsenterer med andre ord den totale adskillelse af slagmarken og det rum, som 'krigeren' (i dette tilfælde droneoperatøren) opererer i. I den forstand fremstår de bevæbnede droner som radikalt anderledes.

Til sidst er det på sin plads med et kig ud i fremtiden. Det er nemlig efter vores opfattelse ret oplagt, at den hastige udbredelse af ubemandede våbensystemer vil gøre netop moralpsykologiske dispositioner vis-i-vis risikofri krig til et væsentligt emne for fremtidig forskning. Det amerikanske forsvar har for nylig annonceret, at man i de kommende år vil satse massivt på ny teknologi, og intet tyder på, at den dagsorden ikke også kommer til at ramme USA's allierede (Mujamdar 2016). Dronerne kommer i stort 
tal, men hvordan vil det påvirke vores oplevelse af væbnet konflikt? Hvordan udvikler ubehaget sig, når ubemandede systemer til lands, vand og i luften bliver langt mere udbredte? Og kommer ubehaget til at betyde mere regulering af dronekrig? Udviklingen kan basalt set gå i to retninger: Vi kan udvikle samme lede ved dronerne, som tidligere generationer har udviklet imod brugen af eksempelvis giftgas, biologiske våben og personelminer; men vores kollektive moralpsykologiske oplevelse af de ubemandede systemer kan også ændre sig, som det var tilfældet med eksempelvis armbrøsten, ubåden og kampflyene. Fra indledningsvist udbredt ubehag til total accept af det nye. Vores forsigtige gæt er, at udviklingen vil komme til at minde mest om sidstnævnte scenarie.

Litteratur

Clausewitz, C von 1976 [1832], On War, M. Howard \& P. Paret (red.), Princeton, N.J. Princeton University Press.

Coker, C 2002, Waging War Without Warriors? The Changing Culture of Military Conflict. London, Lynne Rienner Publishers.

Creveld, M van 1991, The Transformation of War, New York, The Free Press.

Elbe, J von 1939, 'The Evolution of the Concept of the Just War in International Law', American Journal of International Law, vol. 33, pp. 669-70.

Emmerson, B 'Report of the Special Rapporteur on the Promotion and Protection of Human Rights and Fundamental Freedoms while Countering Terrorism', A/HR/C/25/59, 28. februar 2014.

Kaag, J \& Kreps, S 2014, Drone Warfare, Cambridge, Policy Press.

Killmister, S 2008, 'Remote Weaponry: The Ethical Implications', Journal of Applied Philosophy, vol. 25, no. 2, pp. 121-133.

Kilcullen, D \& Exum, A 2009 'Death from Above, Outrage from Below', New York Times, 16. maj 2009.

Margalit, A \& Walzer, M 2009, 'Israel: Civilians and Combatants,' The New York Review of Books, 14. maj 2009.

McMahan, J 2004, 'The Ethics of Killing in War', Ethics, vol. 114, pp. 693-733.

McMahan, J 2009, Killing in War, Oxford, Clarendon Press.

McMahan, J 2013, 'Foreword', in B J Strawser (red.), Killing by Remote Control: The Ethics of Unmanned Military, Oxford, Oxford University Press.

Mujamdar, D 2016, 'Is the US Army Ready for a Shocking Technological Revolution in Land Warfare?', The National Interest, June $23^{\text {rd }}$. Available at: 
http://nationalinterest.org/blog/the-buzz/the-us-army-ready-shockingtechnological-revolution-land-16703.

Kahn P 2002, 'The Paradox of Riskless Warfare', Philosophy \& Public Policy Quarterly, vol. 22, no. 3, pp. 2-8.

Stanford University \& New York University (2012). Living Under Drones: Death, Injury, and Trauma to Civilians from US Drone Practices in Pakistan. Available at: http://livingunderdrones.org/.

Steinhof, U 2014, 'Killing Them Safely: Extreme Asymmetry and Its Discontents' in B J Strawser (red.) 2010, 'Moral Predators: The Duty to Employ Uninhabited Aerial Vehicles', Journal of Military Ethics, vol. 9, no. 4, pp. 342-368.

Strawser, B J 2013a, (red.) Killing by Remote Control: The Ethics of Unmanned Military, Oxford, Oxford University Press.

Strawser, B J 2013b, 'Introduction: The Moral Landscape of Unmanned Weapons' in Killing by Remote Control: The Ethics of Unmanned Military, B J Strawser (red.), Oxford, Oxford University Press.

Walzer, M 2004, Arguing about War, New Haven, CT, Yale University Press. 